\title{
Images in T.S. Eliot's the Waste Land
}

\author{
V. Beulah Rani \\ Lecturer in English, Hindu College, Guntur \\ beulah77v@gmail.com
}

\begin{abstract}
Thomas Stearns Eliot OM, was an American - born British essayist, publisher, Playwright, literary and social critic and one of the twentieth century's major poets. His friend Ezra pound reduced the waste land it to half its size, consists of 5 sections. 1) The Burial of the Dead, 2) A game of Chess, 3) The Fire Sermon, 4) death by Water and 5) What the thunder said.
\end{abstract}

The first four parts of 'The Waste Land' are made up of sets of what may be called images. Eliot speaks through many voices and characters in the course of the poem; all of them see what is around them as a waste land. The reader gets a variety of insights into the state of consciousness which the poem is portraying part 1 deals with memories, II \& III consciousness is focused on points outside it. Part IV to some extent is a proper part of 'The Waste Land' presents an ambiguous image of death, Part V brings the poem to a kind of climax. 'The Waste Land' to a single sentence it might be - the waste land consciousness life is dream - like, nasty, arid, lacking in all order and long.

Most of the images in Eliot are drawn from myth, religion and nature and are central round the basic theme of death and rebirth.

The waste land is infact a difficult but not an obscure poem once we understand its basic themes and symbols and images, its mythical technique the wide knowledge of the poet the poem becomes intelligible to us.

Eliot himself confesses the difficulty of his composition his state of mind can be well understood in his own words.

"It is impossible to say just what I mean, but as if a magic. Lantern threw the nerves in patterns on a screen"

- from the love song of Prufrock.

"The poet must become more and more comprehensive more allusive, more indirect in order to force, the dislocate if necessary, language into his meaning" - says the author of the most controversial poem "The Waste-Land", in his essay "The Metaphysical Poets".

Thomas stearns Eliot OM, better known by his pen name T.S. Eliot, was an American-born British Essayist, Publisher, Playwright, Literary and social critic and "One of the twentieth century's major poets". The waste-land is a long poem, which is widely regarded as one of the most important poems of the $20^{\text {th }}$ century and a central text in modernist poetry.

T.S. Eliot has been accused of obscurity and pretentiousness for writing difficult poetry. The waste land is an extremely difficult poem and hence Eliot provided notes to it. The waste-land - as we have it today, is the result of drastic cuts by his friend Ezra pound. Eliot called him "The better craftsman" for editing the manuscript of the poem and reduced it to about half its size. It consists of 5 sections. Viz-1) The Burial of the dead, 2) A game of chess, 3) The fire sermon, 4) Death by water and 5) What the thunder said. All these names carry special significance and meaning. Though 'The waste-land seems to have no logical structure or continuity of development, We have in the episodes, images, ideas and reflections; apparently is left to his own device to go from passage to passage.

But behind this poem lies Eliots sufferings, travels recollections of his London, his sickness, his torments, his talk with a Lithuanian girl, his imprudent marriage and his love of music and oriental languages. 


\section{Beulah Rani}

The poem provides an Epigraph to the poem-Sibyl of cuemae hanging in a glass bottle, and she always says I long to die. This epigraph indicates the main theme or emotion of the poem. It presents an image of literally suspended life (death in life - as Cleanth Brooke calls it) By the Epigraphy we infer that he prefers to continue in this kind of life. He also provides a dedication; it is done to the American poet Ezra pound, in recognition of his services in revising and abridging his poem.

The first section called "The Burial of the dead", towards the end of it a question is asked about a corpse planted the previous year in a garden. In the second section 'A game of chess' there is a daring reference to insensitive modern man and sterile lust. In waste land love has been replaced by lust. 'The fire sermon' - the third section deals with the persuit of aimless pleasures. The fourth section 'death by waster' remindes us of the survival of consciousness after death, the last section 'what the thunder said' speaks about divine guidance in our spiritual quest without our being aware of it. Thus waste land is a mosaic of literary fragments.

The first four parts of 'the waste land' are made up of sets of what may be called 'images', Eliot speaks through many voices, and characters in the course of the poem; all of them see what is around them as a waste land. The reader gets a variety of insights into the state of consciousness which the poem is portraying Part 1 deals with memories, which although supposedly dead and buried, return to trouble the speakers, or remind them of brief moments of richer existence. Most of their thoughts soon transform into dream or nightmare. It is chiefly concerned with the world within the mind, where as in part II \& III consciousness in focussed on points outside it; a woman's dressing room, a London pub, riverside love, typist's bed sitter are fragmented images and create doubtful inferences to the wasteland mind. Part IV to some extent is a proper part of 'The waste-land' presents an ambiguous image of death. Part- $\mathrm{V}$ bring the poem to a kind of climax. The waste land experiences and disintegrates into a kind of phantasmagoric nightmare in which the central figure makes a piligrimage to an empty chapel where he measures the value of his life thunder to give, sympathise and control. His self examination which reveals the barrenness of his existence enables him to achieve a certain peace of mind.

Although he still sees the world as a waste land, he accepts his lot. If one had to reduce 'The waste land' to a single sentence it might be:- the waste land consciousness life is dream - like, nasty, arid, lacking in all order and long.

The story and the setting which form the background of Eliot's poem is as follows - a person known as the fisher king was the guardian of the Grail. He figures in many fertility rites. The name of Amfort - as is also in use for him. As he fails to protect virgins offering worship at the chapel, he suffers a wound and becomes imposent. His land is cursed, it loses its fertility and becomes a waste land. The discovery of the Grail by a pure and innocent knight alone could heal the wound of the fisher king and restore fertility of the land. Many made the attempt, but few succeeded. The protagonist undertakes a pilgrimage of the soul, a quest for spiritual peace and enlightenment. Like the knight seeking the grail he too finds himself in the chapel perilous, where he encounters horrors. He leaves the chapel disappointed. The protagonist after leaving the chapel, learns what spiritual virtues he has to cultivate in order to allain the peace of God. 'Waste land' is the name of the kingdom ruled by the Fisher King.

Conrod Aiken described 'The waste land' as a series of sharp, discrete perceptions and images dramatically and lyrically presented. He adds that we are thus invited into a world of broken bundle of mirrors and a heap of broken images. These images are juxtaposed and do not relate to one another. Yet these images strike the mind's eye. Leonard anger offers a list of images that are found in Eliot's poetry. They are -1) Water images of various kind especially under water, 2) City Streets, 3) Human Hair, 4) Stairs, 5) of Music and 6) of smell.

The images of stairs is a common imagery in Eliot's poems. Footsteps on the stair indicates the arrival of a person into the room. The only direct means by which his presence is indicated. Eg: "Footsteps shuffled on the stairs".

- "A game of chess"

And again in "The fire sermon" - The young man's retreat is indicated, "And gropes his way, finding the stairs unlit".

The groping and the stairs being unlit give this image a symbolic quality. Both the stair images in the waste land have a symbolic inclination one image is about a man's arrival and the other of a man's 
departure. Each of these images involves a troubled encounter between a man and a woman. Between the typist and the young clerk.

The imagery of smell is also very frequent in Eliot's poetry. In his poems we feel the stale smell of beer, paper roses, smells of dust, female smells, can de cologne, in shattered rooms.

They convey the theme of sexual anxiety. The opening lives of "A game of chess" there is an elaborate imagery of "the strange synthetic perfumes" of a woman whose "nerves are bad to night".

Most of the images in Eliot are drawn from myth, religion and nature and are centred round the basic theme of death and rebirth. Thus spring stands for re-birth and winter for death, drought for spiritual dryness and rain for spiritual fertility, growth and rejuvenation, the rock under the sun may typify spiritual disintegration, while water and fish may stand for growth. Here in the 'waste land' the drowned phonician sailor stands for the fertility God thrown into the waters as a ritual.

Broadly speaking there are two groups of images in Eliot's poetry - viz simple images such as similies, metaphors, symbols and pictures. There are numerous, examples for simple images in waste land. These might be called as pictures.

There are - pictures of the hyacinth girl, marie of Germany. There is madame sosostris the clairvoyant, the crowd crossing London bridge on winter morning (a picture of desolation) and a bar in the pub. There is the Thames and Mr. Eugerides; the typist and her sordid clerk and finally in the last section the mistier pictures of crowds in anger and revolution and the mysterious third person who can only be seen as you walk long (Jesus after resuruction - Journey to Emmavs).

And the surrealistic woman playing music on stretched - out hair as if it were a violin. Thus Eliot has made use of liberal use of similies and Metaphors. These similes and metaphors in poet a clear impression of what the objects described are like and also the emotional impact of those objects. For example -

"April is the cruelest month, breading lilacs"

- The Burial of the dead

"The corpse planted in the garden"

- The Burial of the dead

"The River tent is broken"

- The Fire Sermon

"Limp leaves and singing grass - What the thunder sunken Ganga"

said etc.

The songs of the birds are also significant. The poem describes them phonetically. The Jug Jug Jug of the Nightingale, drip drop drip drop song of the hermit thrust and the coco rico coco rico of the cock have special symbolic meaning. All these are arresting images.

The phrase objective correlative occurs in Eliot's essay on 'Hamlet and his problems' in sacred wood. It was first used by American painter and poet Washington Allston to describe artistic relationships to emotion sometime around 1840. Eliot rediscovered the concept and popularized it throughout his career though several critics over the years have opposed the notion as he conceived it. In 'Hamlet and His Problems', Eliot conceptualized the objective correlative like this.

"The only way of expressing emotion in the form of art by finding an objective correlative in other words, a set a of objects, a situation, a chain of events which shall be the formula of that particular emotion, such that when the external facts, which must terminate in sensory experience, are given, the emotion is immediately evoked.

To maintain the structural coherence Eliot makes use of the suitable objective correlatives and to advocate his main theme that passions arise from original sin, he makes use of the legendary story of fisher king and the Holy Grail. Many bold knights lost their lives in the arduous task of its quest and rediscovery. Tennyson also treated this theme in his Idylls of the King. Miss Weston in her "From Ritual to Romance" has given life to the story of the wasteland. The wasteland is an allegorical application of this story to modern society and religion. 


\section{Beulah Rani}

The phrase has been used by Eliot to explain how emotion can be best expressed in poetry. This means that certain objects or words have the power to communicate the emotion felt by the poet to the reader. The waste land is full of objective correlatives of a complex emotions. So Eliot therefore relies on images, music and suggestive phrases which stir up feelings and help association of ideas. In the waste land, where the emotions aroused in the reader are not expressed directly by the poet but by disconnected ideas and images. Whereas other poets have achieved by using a series of connected sentences. The most curious example of Eliots method is found in the string of quotations from various languages which concludes the poem. A hint is given that these are fragments that the protagonist has stored up against his ruins.

Eliot explains how emotion can be best expressed in poetry and it is a part of his impersonal theory of poetry concentrating not on the poet but on the poetry. The theory of impersonal art implies that greater emphasis should be laid upon the work of art itself as a structure. His theories of the objective correlative and the impersonality of art from the most significant aspects of his classicism.

Eliot himself suggests the reader should not question the reasonableness of each imagery. The waste land is a long narrative poem. But he claims in every case an arrangement of imagery according to the logic of the imagination. The waste land has a single theme a state of spiritual barrenness. Objective correlatives for it are found in various images, situations, reflections, dramatic dialogues and quotations. The barrenness of man's contemporary spiritual estate is brought home by imagistic forms - sand and dry rock, gas-house ugliness, sandwitch paper letter, vulgarity, prostitution, hysteria, death and half-death.

The title of the poem itself brings an image before our eyes, of a desert, of a land once fertile becoming barren. This image keeps recurring through out the poem. In the very second line "Lilacs out of the dead land" we have the reference to the dead land. A little later it becomes story rubbish. The image is further extended to dead trees under the burning seen and dry stones over which no water trickles. Towards the end the betrayal and trail of Jesus are referred to the track up the barren mountain is described. There is no water but only rock. Even the sweat becomes dry. Thunder is sterile over the mud cracked houses. To add to the misery, the deceptive song of the hermit-thrush by its water dripping song.

Near the Chapel perilous there are empty cisterns and exhausted wells. The song of the dry grass is heard, near in the cemetery dry bones are these dryness and barrenness and the lack of water stand for spiritual state of modern world.

Reference to death and decay in the poem occur frequently Eg: The burried corpse, the drowned phlebas. At the chapel perilous, a cock crows from the roof as lightening flashes, thunder rolls and damp winds. These are hints that death may be a bigning to new life and that drought is not final.

Finally the message of the thunder shows the nakedness of the man in waste land. We give nothing. We show no compassion and we have no self-control and by the episode of ugolino (left to starve to death) graphic picture of spiritual isolation is hinted at. The photogonist feels that he has diagnosed the spiritual illness of the modern world. But diagnosis is not cure.

Thus in waste land the poet primarily relies on images lined together around a fundamental theme. Eliot is not a mere symbolist or imagist, because his poems are more than a mere string of disconnected images. He elicits emotion without directly expressing it, by evoking some situation which by itself arouses emotion. Objective correlatives are very useful in understanding his poetry.

The phrase "dissociation of sensibility" occurs in Eliots essay on the Metaphysical poets. He uses this word to describe the faults of $17^{\text {th }} \mathrm{C}$ Poetry. The opposite for this is unification of sensibility. According to Eliot unification of sensibility produces good poetry and hence the cause of bad poetry is dissociation of sensibility, unification of sensibility means recreation of thought into meaning. Thus when thought is transformed into feelings the result is unification of sensibility. But when thought is not able to converted into feelings, disassociation of sensibility occurs.

Thus the distinction between the two is a split between thought and feeling. A poet may have the best ideas but they are useless till they issue forth feelings. A philosopher has his ideas but a poet is one who can convert his ideas into feelings. In this context waste land is a great poem, when the poet achieve a total unification of sensibility by make use of symbols and images. 
In the poem post war London is mainly shown. Eliot shows us royalty flirting with the beloved on the Thames, slum-dweller in a public house re-hear sing the marriage rituals, a typist having an ugly affair in her hall-cum-bed room, a lady hysterical with loneliness in her rich mansion, Phoenician and symrna tradesmen indulge in homosex. Dante's hell and noman's land etc., heighten the sense of futility and waste. All these fragmentary scenes enacted - as the walls of Troy were built, and reflect in-coherence, the shabbiness, the emptiness and a loveless infertile world.

Going through the wasteland one wonders at the irrisistable attraction of Eliot for the wisdom of ancient India. But for the Indian thought and sensibility the waste land would have been a difficult poem.

The symbolic character of the poem is not merely due to the fact that it is all compact of allusions and moves between dream and nightmare or its mixture of archaisms and modern slang, but to the poet's religious view of life. Eliot himself confesses in his essay 'The use of poetry and the use of criticism' that the personal causes makes a poet express himself in any but an obscure way.

The waste land is in fact a difficult but not an obscure poem once we understand its basic themes, the symbols and images, its mythical technique the wide knowledge of the poet the poem becomes intelligible to us.

The waste land is unintelligible sometimes because of its purposes of symbolism. Eliot himself confesses the difficulty of his composition his state of mind can be well understood in his own words;

"It is impossible to say just what I mean but as if a magic. Lantern threw the nerves in patterns on a screen".

- from the love song of Prufrock.

\section{REFERENCES}

[1] T.S. Eliot - Waste Land

[2] T.S. Eliot and the waste land Psychopathological - Trosman, Harry

[3] T.S. Eliot - Hamlet and his problems

[4] Idylls of King - Tennyson

[5] Eliot, T.S. on Poetry and Poets

[6] Prufrock and other observations - T.S. Eliot

[7] The Dial (The waste land) - T.S.Eliot

[8] The Eliot Four Quarters.

[9] The Waste Land : Themes

[10] T.S. Eliot Waste Land and other poems.

[11] Issues in 'The Waste Land' - T.S. Eliot .

[12] T.S. Eliot. The Longer poems - Travers - Decek.

\section{AUTHOR's BIOGRAPHY}

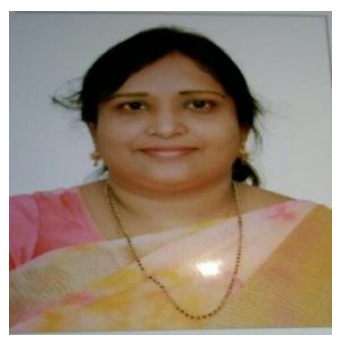

Velpula Beulah Rani, have been in service as a Lecturer in English in this August body since 2000. I have enriched my teaching and language skills by participating in various National and International seminars and workshops. Eight of my research articles have been published in different souvenirs. Three of my research articles have been published in international souvenirs. 